\title{
(Re) Locating Subalterns: \\ A Case Study of Nepalese Ethnic Communities
}

$\sim$ Babu Ram Khanal $^{1^{*}}$, Ph.D.

\section{Abstract}

The locating process of subalterns is vague and an ever challenging task that this article attempts to study. This research contends that the determining parameters of subalterns and of privileged class change with a change in space, time and financial status of an individual. So, our perspective of defining subaltern is very superficial, unjust, full with prejudice and impractical that needs to be redefined and reinterpreted. The caste system which has become only a determinants of locating subalterns, can never be a sole determining factor of subaltern. Instead, it is the financial status that should matter while defining the privileged and subalterns. Thus, this paper aims to relocate subalterns in Nepalese ethnic context.

Keywords: Dominant, subaltern, relocation, marginalization, bureaucracy.

This article tries to delineate a short glimpse of subaltern studies and people's observation, their understanding about and the notions of subaltern which has been time and again misinterpreted, wrongly explained and misrepresented. I believe that the readers would contend that the definition is heterogeneous and it changes in course of time and space and a change in the financial status of people. In such a case number of questions about subalterns can be raised, first, (i) what are the determinants of subalterns? (ii) How do they change in course of time and space? and (iii) Can the definition of subaltern change with a change in the status of people? This article tries to answer these questions in general as well as in the context of Nepalese politics.

Literally, the term subaltern refers to the category of those who are lower in position, who are living in extreme poverty, and on top of that who are cut off from the main steam of politics. Hans Berterns agrees with Gayatri Spivak and Antonio Gramsci and contends that the subaltern are "the homeless, the unemployed people, subsistence farmers and the day labours" (212). Similarly, Pramod Kumar Nayar assumes:

Subaltern (ity) is the history of marginalized communities, gender, race, and 'groups written with locals sources and from their perspectives. It is primarily the history of the common people, the lower classes, the tribals, and the women, whose lives and stories do not figure in main stream history except as audience to the great acts of the dominant classes or groups. (511)

$1{ }^{*}$ Mr. Khanal is an Associate Professor of English Department, Saraswoti Multiple Campus, T.U. 
So, the definition of subaltern is very wide complicated and encompassing. It is the history of those groups and communities, who are in minority, poor financially, have not occupied highest position in politics, and in other affairs of government.

Jim Masselos in The Dis/appearance of Subalterns cites Ram Chandra Guha's query who and what are subalterns? He defines the term in two ways: positively, by outlining who they are: and negatively as a constituent of a binary opposition, by distinguishing what they are not. He further writes;

Subalterns are those of inferior rank, those subordinate in terms of class, caste, gender and office. As an opposition they are not those who are dominant, the ruling groups, the elites foreign officials, industrialist and of the indigenous feudal magnates, the industrial and mercantile, bourgeoisies, upper Indian bureaucrats etc. Elites were dispersed and heterogeneous; significantly, their member might at regional and local levels either be part of the elite or according to circumstances and situation be classified as subaltern. (188)

It becomes obvious that subalterns are those people who are not the major group not even in power or the owners of an industry or factory. They are just the workers who hardly make their living by toil.

In Subaltern Studies: Radical History in the Metaphoric Mode, Henry Schwarz agrees that Guha's definition very clearly tried to return to the original Gramcian perspective, in which subaltern designated the lower strata of an under developed society lacking in naturally revolutionary classes. He writes:

For Gramci, the term, subaltern, used interchangeably with popular classes' or 'masses' described the inferior social position of a small industrial and agricultural proletariat subsisting along side a massive peasantry, all if who were 'left out' if the historic formation of the Italian state in 1870. (47)

Hence, it is obvious that subaltern is not defined in term of caste, creed, class, ideology or religion as it has been done in Nepal, but in term of his financial status, his position and the resources he owns.

Ram Chandra Guha in Subaltern and Bhadra lok Studies occupies his position with similar readings and definitions. He writes:

... a person's subalternity is determined by his economic status which might be changing in course of time and space. A superior might turn to be inferior and privileged might turn into subaltern with the change in the resources and economic status." (18) 


\section{Subaltern (s): A Metaphoric Mode}

In Nepal, the term subaltern has to be reinterpreted in course of time and space. The People's Movement of 2063 (2007 AD) not only overthrew the two hundred forty years old monarchical structure of Shah dynasty but also opened its space for the study of different discipline of post-colonial studies. The study of different class, race, religion, gender and even highly marginalized communities were carried out with its new horizontal and vertical explanations. In other words, the study of subaltern emerged. But the study and exploration of subaltern appeared to be vague, ambiguous and misinterpreted. Subalterns were defined not on the basis of their financial status and the resources they possess but on the basis of their caste.

This interpretation has been unfair in the sense that any Brahmin or Chhetry even from far remote regions of Nepal is declared as privileged class. Brahmin or Chhetry, may be, a rickshaw puller, a vendor, a ploughman, a day labor or in Spivak's term a subsistence farmer, a porter with a bamboo basket on his back waiting at Kalimati, Kalanki, or Balaju bus station to carry the elite bourgeoisie subaltern's luggage, are labeled as subalterns. On the other hand, the highly sophisticated billionaire, the promoter of 'A-Grade' bank, the owner of A-Grade private school/college and the departmental store owners and contractors are labeled as subaltern and marginalized on the basis of their caste. Not only that the investors in hydro-power, the industrialists who have major holdings in the corporate organization, business and country's economy have no hesitation to call themselves subaltern and inferior, and seek reservation (12).

These subalterns' have got reservation in bureaucracy, corporate organizations, hospitals and even for members of parliament. For them, job in ICIMOD, UN and other INGO is secured. Not only that they get reservation in foreign ministry, army and other confidential departments. The recent advertisement for the position of school teachers is evidence in this regard (Gorkhapatra) They have been able to secure their position in such remote regions where they have never steeped out or heard about them. On the other hand, the Brahmins and the Chhetry who were born, brought up there and whose fore-fathers have been living there for centuries and whose financial status is much lower than the state declared subaltern, have no reservation. Nothing can be as appalling, injustice as this for a civilized democratic nation where subaltern is determined on the basis of caste and race.

\section{Subaltern Studies: Insufficient Definition}

To quote Gramsci (306), Guha (189), Nayar (51), and Spivak (212), subalterns are defined on the basis of a person's financial status, jobs and other resources they own 
provided that they may be of any color, caste, religion or ideology. Economic status always becomes a primary determinant. The interim constitution of Nepal 2063 has given equal opportunity to all its citizens. Any citizen can compete in any position of the civil service, corporate office, health and other organizations notwithstanding he is competent. He can join university, pursue higher education, stay in motels and hotels, borrow books from library and drink water from the same tap and worship in the same altar. Not only that he can move freely to any part of the country without any arms, give speech, write books, can invest and acquire land in any part and place. So, why should he seek reservation forcefully by imposing strike, vandalizing government as well as private property, by kidnapping ordinary citizens and killing them? The political parties, the parliamentarians, the architects of the interim constitution, without defining subaltern properly labeled some sects of people subaltern to fulfill their immediate vested interest of 'vote'. I never mean to say that there are no subaltern, I mean there are elite subaltern. The real subaltern does not have much excess in schooling, in job or in power sharing. My purpose is not to underestimate any class, caste or religion but to focus a bourgeoisie subaltern, the privileged classes who have been getting advantage much from the state at the cost of real subaltern. Mallon points out that "complicity, hierarchy and surveillance within subaltern communities... make clear that no subaltern identity can be pure and transparent, most subalterns are both dominated and dominating subject" (134). With due honor I would like to quote the name of some reverend businessmen and industrialist like Jyoti, Golcha, Chaudhary, Dugar, Rai, Agarwal, Gurung who have in one way or the other greatly contributed the nation, but my concern is providing them the logo of subaltern and providing magnates reservation.

\section{Construction of Binaries and Issues of Subaltern}

Levi Strauss (62) and Edward Said (205) believe that the structure of primitive thinking is binary. Strauss blames the ancestors who at first created differences on the basis of conscious awareness between human beings and animals. Said assumes that the formation of binary between the East and West has exposed over all dominant nature and centrality and superiority over the Orient. I believe that Westerners' effort to portray them always masculine, enlightened, rational, disciplined and entrepreneurial is groundless. They have viewed Brahmins and Chhetry with similar lens and spectacles. Their interference through INGO in developing countries like Nepal has helped in the creation of negative understanding among the different caste, tribe, race and religion. On top of that INGOs have inappropriate means to picture the Nepali aborigine Brahmin and Chhetries as elite by birth and other sects of people as subaltern and 
forced the mirror staged political leaders of Nepal to give consent in the formation of elite subalternity on the basis of caste.

\section{Colonized and the Colonizer}

Nepalese political leaders time and again express their inferiority and superficiality of their knowledge and understanding. They use subaltern, marginalization and colonization innocently to define the oppressed and the marginalized. Their definition is either full of prejudice or lacks the spirit of education or they want to make an escape to get the 'vote' politics. These political leaders fail to approach any of the standard definition of subaltern. To them, subaltern are born from their caste. They label Brahmin and Chhetry as born colonizer provided that they might come from any remote corner from extreme poverty and other caste as inferior and colonized. Their accountability for the nation and responsibility for people becomes secondary. Their claim does not match with Bhabha and Aime Cesaire. Bhabha writes there is no cultural interaction between the colonizer and colonized (206). Aime Cesaire, in his book" Discourse on Colonialism defines the colonizer and colonized thus:

... that between the colonizer and the colonized there is no human contact, but relation of domination and submission which turn the colonizing man into a classroom monitor, an army sergeant, prison guard, a slave driver and the indigenous man into an instrument of production. (1997: 81)

Cesaire's explanation goes in harmony with Guha (189), Gramsci (212), Bhabha (206) and Spivak (26) but it contradicts with Nepalese parliamentarians. Some Brahmins and Chhetrys, I agree, have got privileged position, while many others are basket carriers as Cesaire says, porters of the elite subalterns, their drivers and their guards, workers and gardeners. Yet they are labeled as elite bourgeois, colonizers and privileged by birth . ... The so called deprived maybe the President, Speaker of the House, industrialists, owners of A-grade institution's but are always declared subalterns. Nothing can be as injustice as this. Person with high financial status is a born subaltern, a colonized, on the one hand, a person with low financial status, and searching his fortune on the grace and kindness of the state declared subaltern, is a born colonizer (33).

In Oxford Concise Dictionary of Politics, Ian Me Millian et.al write, in India, Mandal Commission planned for 49.5 percent reservation for women as they were in a state of colonized, confined in poverty and household chores, but because of political protest that couldn't materialize. Ian further writes in 1990 the reservation of seats 
in local government was extended to women although caste based intervention have undermined attempts to introduce legislation to secure one-third quota for women in the Indian parliament.... But they have also" perpetuated caste division and their effectiveness in improving, the social economic position of the wider population rather than just a "creamy layer" of beneficiaries is likely to be limited" (187).

\section{Elite and Subaltern: Homogeneous vs Heterogeneous}

Gayatri Spivak, in her essay 'Can Subaltern Speak' constructs a definition of elite as:

i. Dominant Foreign Groups

ii. Dominant Indigenous Groups at the Nation Wide Level

iii. Dominant Indigenous Groups at the Regional and Local levels (26).

Spivak's definition clearly and consciously points out that any dominant tribe in the national, regional or local level is an elite. He is no more a subsistence farmer or a day laborer, as Gramsci and Spivak believe but an elite and privileged class. Therefore, the category of defining subaltern is not homogeneous but uneven and heterogeneous because of regional economic and social development. Jim Masselos assumes that "the elites were dispersed and heterogeneous; significantly, their members might in regional or local levels according to the circumstances and situations be classified as subaltern" (2008:189). In Nepal, a privileged class Brahmin or Chhetry from remote regions of Jajarkot or Taplejung can be a subaltern in Janakpur or Kathmandu. In a similar case, an owner of four anas of land in the down-town of Kathmandu and Pokhara can be much richer than owners of four bighas of land in remote of Kapilvastu or Gorkha. Guha argues:

The same class or element which is dominant in one area... could be among the dominated in another. This could and did create many ambiguities and contradictions in attitude and alliances especially among the lowest strata of the rural gentry impoverished landlords rich peasants and upper middle class peasant all of whom belonged, ideally speaking to the category of people or subaltern classes. (1982: 8)

Hence there is no such homogeneous category of defining subaltern. The nature of subaltern differs in time and space, let alone caste system as in Nepal. It varies from one locality to other localities because the place and time changes subaltern into a privileged class and vice versa. They are no more a feminist but masculine, independent privileged class, phallocentric. 


\section{Conclusion}

To coin Gramsci, Guha, Spivak, Nayar, Bhabha, Strauss and Cesaire, a person is not subaltern by caste or religion or a colonizer and privileged. It is his financial position, his status in the community which determines whether he is a subaltern or privileged. A primary level school teacher or a government official with his same position draws about, Rs. 24,000 (NRs). whereas a person with similar status might earn Rs. 60,000 in ICIMOD, UN office, Red Cross or Standard Chartered Bank. The former, despite his caste and ideology is subaltern while the latter a privileged. Hence, it would not only be unwise but sole foolishness to use caste as a determinant, and a measuring rod of subaltern. Similarly, a privileged person of a time could be a subaltern with the change in time and space. The duty and responsibility of a civilized nation is to identify, at first, without any prejudice who the subalterns are, issue them certificate and launch program in order to uplift their status. There should be a nation wide debate and discussion among all sects of people, academicians irrespective of their caste, creed, ideology and religion to ensure unity and harmony among the citizens. Or if a state tries to give reservation at the cost of others, it could be a bone of contention, cause of disharmony and disintegration.

\section{References}

Bertens, Hans. The Basics: Literary Theory. London and New York: Routledge, 2003: 205-2 1 .

Bhabha, Homi K. "Redrawing the Boundaries: The Transformation of English and American Studies." Post Colonial Criticism. Ed. Stephen Greenblatt and Giles Gunn. New York: MLA, 1992.

Cesaire, Aime. "Discourse on Colonialism." Postcolonial Criticism. Ed. Bart MooreGilbert, Gareth Stanton, et.al. London: Longman, 1997.

Guha, Ramchandra. "Subaltern and Bhadralok Studies." Economic and Political Weekly, 30, August 19,1995:256-8. Vol. 30, no. 19, August, 1995, pp. 256-8.

Levi-Strauss, Claude. The Way of Masks. Seattle University ofWashington Press, 1982.

Mallon, Florencia E, The Promise and Dilemma of Subaltern Sudies: Perspective from Latin American History, American Historical Review, 1994.

Masselos, Jim. "The Dis/appearance of Subalterns: A Reading of a Decade of Subaltern 
Studies" Reading Subaltern Studies. Ed. David Ludden. India: Permanent Black, 2008: 187-211.

Mc Million, Ian et.al. Oxford Concise Dictionary of Politics. India : Oxford University Press. 2006:464

Nayar, Pramod K. Subaltern Studies Post Colonial Literature. India: Pearson, 2008: 51. Said, Edward. Orientalism. Harmondsworth: Penguin, 1991.

Schwarz, Henry. "Subaltern Studies Redical History in the Metaphoric Mode." Subaltern Studies. Ed. David Ludden, New Delhi: Permanent Black, 2008: 304-343.

Spivak, GayatriChakravorty. "Can Subaltern Speak?" The Post-Colonial Studies Reader. Bill Ashcroft, et. al. (eds.) London: Routledge, 1995: 24-28.

The constitution of Nepal 2063

The Gorkhapatra. Gorkhapatra Sansthan, Kathmandu, 2070. 